\title{
Erythropoietin as an antiapoptotic, tissue-protective cytokine
}

\author{
P Ghezzi ${ }^{\star}, 1,2$ and M Brines ${ }^{2}$ \\ ${ }^{1}$ Laboratory of Neuroimmunology, 'Mario Negri' Institute, Milan, Italy; \\ 2 Kenneth Warren Institute, Ossining, NY, USA \\ * Corresponding author: P Ghezzi, Laboratory of Neuroimmunology, 'Mario \\ Negri' Institute, via Eritrea 62, 20157 Milan, Italy; E-mail: ghezzi@ marionegri.it
}

Received 16.2.04; revised 29.3.04; accepted 02.4.04

Edited by Dr G Melino

\begin{abstract}
Erythropoietin (EPO) increases the number of circulating erythrocytes primarily by preventing apoptosis of erythroid progenitors. In addition to this proerythroid action, results of recent studies show that systemically administered EPO is protective in vivo, in several animal models of neuronal injury. In vitro, EPO prevents neuronal apoptosis induced by a variety of stimuli. This review summarizes the neuroprotective actions of EPO and discusses the underlying mechanisms in terms of signal transduction pathways involved. The understanding of these mechanisms will help differentiate the neuroprotective actions of EPO from its role in the bone marrow.
\end{abstract}

Cell Death and Differentiation (2004) 11, S37-S44.

doi:10.1038/sj.cdd.4401450

Keywords: erythropoietin; neuron; neurodegeneration

Abbreviations: AMPA, amino-3-hydroxy-5-methylisoxazole-4propionic acid; CNS, central nervous system; EPO, erythropoietin; EPOR, EPO receptor; GFAP, glial fibrillary acidic protein; HIF, hypoxia-inducible factor; IGFBP, insulin-like growth factor binding protein; NMDA, N-methyl-D-aspartate; NO, nitric oxide; VEGF, vascular endothelial growth factor

\section{Introduction}

Erythropoietin (EPO) was named for its long-appreciated hormonal effect of maintaining the circulating erythrocyte mass. In recent years, however, it has been recognized that EPO is a member of the cytokine type I superfamily. Typical for cytokines, EPO has multiple functions outside of the bone marrow. Many of these effects parallel its action in hematopoiesis, where EPO functions to promote proerythroblast survival and maturation. Over the last 10 years, a prominent role for EPO has been defined in the nervous system and there is a growing interest in the potential therapeutic use of EPO for neuroprotection. In this review, we will outline the mechanism of action of EPO in erythropoiesis with a focus on inhibition of apoptosis. This concept will then be extended to examine the neuroprotective activities of EPO, which in addition to a critical role in antiapoptosis, also embody other beneficial actions.

\section{Erythropoietin is a cytoprotective cytokine induced by the hypoxia inducible factor family}

EPO is the hematopoietic factor responsible for the production of red blood cells and for this function is produced mainly by the adult kidney. EPO is induced by hypoxia via the hypoxiainducible factor (HIF) family of transcription factors. This growing family mediates physiological adaptation to low tissue oxygen concentration (such as that encountered by high altitude or anemia) ultimately resulting in an increased number of erythrocytes within the circulation and therefore improved tissue oxygenation. Along the same line, HIF also regulates genes for neoangiogenesis (e.g., vascular endothelial growth factor, VEGF) as well as for vascular tone (e.g., nitric oxide (NO) synthase).

While erythropoiesis and angiogenesis represent adaptive responses to improve tissue oxygenation that require several days to develop (for instance, the time required for EPOmediated appearance of mature erythrocytes in the circulation is about a week), HIF also mediates short-term adaptive responses to hypoxia, and several glucose transporters and glycolytic enzymes are transcriptionally regulated by HIF, as well as genes involved in cell growth and survival including insulin-like growth factor 2 and IGFBP (reviewed in: Semenza, ${ }^{1}$ Wiesener and Maxwell ${ }^{2}$ and Wenger $^{3}$ ). The induction of glycolytic enzymes demonstrates a role for HIF in the metabolic, cell-autonomous adaptation to hypoxia represented by the switch of ATP generation from oxidative phosphorylation to glycolysis, the Pasteur effect. ${ }^{4}$ It has also been suggested that, because HIF is often constitutively expressed in tumors, it may mediate the high constitutive expression of glycolytic enzymes that is the basis of the Warburg effect. ${ }^{3,5}$

The metabolic changes induced by hypoxia clearly play a role in ischemic preconditioning, a well-known phenomenon, reported for various organs including the heart, brain, kidney and liver, whereby pre-exposure to hypoxia (such as a minor ischemic event) protects from subsequent, severe ischemia. ${ }^{1}$ Activation of HIF and/or pre-exposure to hypoxia also protects neuronal cells from apoptosis induced by oxidative stress. ${ }^{6}$

However, HIF-mediated protection from apoptosis may also involve other hypoxia-inducible cytokines implicated in the physiological responses to hypoxia, such as EPO and VEGF. In fact, there is much evidence showing that EPO protects neuronal cells in vitro, an action independent of its erythropoietic activity. In particular, EPO not only protects neurons from cell death induced by hypoxia, but also from a variety of other agents including excitotoxins and glucose deprivation (Table 1). More recently, it was reported that 
Table 1 Neuroprotective effects of EPO in vitro (selected references)

\begin{tabular}{lll}
\hline Type of neurons & Type of toxicity & Effect of EPO \\
\hline Motor neurons & Kainate & Protection \\
Hippocampal neurons & Hypoxia & Protection \\
PC12 cell line & Serum/NGF deprivation & Protection \\
P19 cell line & Serum deprivation & Decreased apoptosis \\
Hippocampal neurons & Anoxia & Decreased apoptosis, Caspase activation \\
Cortical neurons & NMDA, NO & Decreased apoptosis \\
Hippocampal and cortical neurons & Glutamate & Protection \\
Primary cortical & Oxygen/glucose deprivation & Decreased apoptosis \\
Hippocampal neurons & NO & Protection \\
Cortical neurons & Oxygen/glucose deprivation, AMPA & Protection \\
Hippocampal neurons & Chemical hypoxia & Decreased apoptosis
\end{tabular}

VEGF is also a neuroprotective and trophic factor for neurons. $^{7-9}$

The finding that systemically administered EPO, a widely used drug with a well-known safety profile, crosses the bloodbrain barrier in rats and in humans ${ }^{10,11}$ and has protective effects in various models of nervous system injury (Table 2), has greatly focused attention on the neuroprotective actions of EPO and the underlying mechanisms. The protective effects of EPO are not restricted to the CNS as it was recently shown that EPO has also antiapoptotic effects on cardiomyocytes in vitro and in vivo in a rat model of myocardial infarction, where it normalizes hemodynamic functions. ${ }^{12}$ All these data stress the importance of EPO as an antiapoptotic and cytoprotective, not only neuroprotective, cytokine.

\section{Inhibition of apoptosis in the hematopoietic activity of EPO}

Erythrocyte development proceeds from progenitor cells that require multiple growth factors to initiate cellular differentiation. Cells entering into development express receptors for EPO (EPOR) during specific phases in differentiation and unless EPO is present during the critical period, the progenitors will undergo apoptosis. EPO specifically augments the number of circulating erythrocytes by promoting the survival and therefore enabling the proliferation and differentiation of erythroid progenitor cells. ${ }^{13,14}$ Although EPO, through the EPOR, can effectively support the proliferation of murine erythroid progenitor cells ex vivo ${ }^{15}$ and induce the entry of erythroid progenitors into cell cycle if dormant, ${ }^{16}$ promotion of survival due to prevention of apoptosis of late erythroid progenitors is thought to be a major mechanism in EPO action. ${ }^{17,18}$

Using the EPO-dependent human erythroid progenitor cell line HCD-57, Silva et al. ${ }^{19}$ showed that EPO maintained their viability via repressing apoptosis by upregulating $\mathrm{Bcl}-\mathrm{xL}$, an antiapoptotic gene of the $\mathrm{Bcl}-2$ family. When these cells are cultured in the absence of $\mathrm{EPO}, \mathrm{Bcl}-2$ and $\mathrm{Bcl}-\mathrm{xL}$ are downregulated and the cells undergo apoptosis. ${ }^{19}$ To further support the importance of this pathway, Bcl-xL knockout mice exhibit fetal liver hematopoietic defects and severe anemia during embryogenesis. ${ }^{20}$

EPO exerts its erythrodifferentiating effect via the EPOR, which belongs to the hematopoietic growth factor receptor superfamily. Other members include receptors for IL-2 beta chain, IL-3, IL-4, IL-5, G-CSF, GM-CSF, thrombopoietin, growth hormone, prolactin and the receptors for several cytokines of the IL-6 family (IL-6, leukemia inhibitory factor (LIF), ciliary neurotrophic factor (CNTF) and oncostatin M). ${ }^{21,22}$

One possible signal transduction pathway involved in the antiapoptotic action of EPO in erythroid cells is outlined in Figure 1, based on the known signal transduction pathways activated by EPO (excellently reviewed in Wojchowski et $a .^{23}$ ). Binding of EPO to the extracellular domain of preformed EPOR dimers ${ }^{24}$ initiates signaling that in turn results in recruitment and activation of Janus kinase 2 (JAK2) by the intracellular domain of EPOR. JAK2 then phosphorylates several proteins including STAT5. There is evidence in favor of a role of STAT5 in the antiapoptotic action of EPO on erythroid precursors. In particular, STAT5 appears to mediate the induction of $\mathrm{Bcl}-\mathrm{xL}$ by EPO, ${ }^{25}$ and anemia and high levels of apoptosis in erythroid progenitors are observed in STAT5 knockout mice, possibly due to a disruption of the $\mathrm{Bcl}-\mathrm{xL}$ response pathway. ${ }^{26}$ Further, EPOR activation activates voltage-sensitive $\mathrm{Ca}^{2+}$ channels, which in turn modulates neurotransmitter. ${ }^{27}$

Another pathway involves activation of phosphatidylinositol-3 kinase $(\mathrm{PI} 3 \mathrm{~K})$. In fact, $\mathrm{PI}(3) \mathrm{K}$ is activated by EPO in the EPO-dependent UT-7 leukemia cell line, where it recruits Akt. ${ }^{28}$ This PI3K-Akt pathway also leads to upregulation of $\mathrm{Bcl}-\mathrm{xL}$ and inhibition of apoptosis in Baf-3 cells. ${ }^{29} \mathrm{~A}$ further mechanism could be represented by NF-kB that is also a target of the PI3K-Akt pathway and mediates antiapoptotic signaling by platelet-derived growth factor. ${ }^{30}$

\section{EPO as a neuroprotective agent}

Study of experimental brain ischemia has shown that EPO and EPOR function as components of an innate response to metabolic stress. Multiple studies have shown that whereas normal brain expresses both EPO and EPOR in a highly restricted and limited manner, following ischemic and other stressors a marked induction of both proteins occurs in animal models ${ }^{31}$ as well as in human disease. ${ }^{32,33}$ Presumably, this regulation is accomplished by specific proinflammatory cytokines, for example, TNF-alpha, IL-1 and IL-6. ${ }^{34}$ Temporally, EPOR upregulation occurs first by $12 \mathrm{~h}$, primarily in neurons and endothelial cells of the microcirculation, followed hours later by an increase in EPO by both astrocytes and neurons. ${ }^{31}$ These effects are especially prominent in the 
Table 2 Nonexhaustive listing of in vivo models of tissue injury showing nonclassical activities of recombinant human EPO

\begin{tabular}{|c|c|c|c|c|c|}
\hline Tissue & Model & Species & Method/dosing & Effect of EPO & Ref. \\
\hline Brain & Ischemia-reperfusion & Rat & $\begin{array}{l}\text { Three-vessel occlusion. Single i.p. } \\
\text { dose }\end{array}$ & $\begin{array}{l}\text { Reduction of stroke volume by } \\
275 \% \text {; partial efficacy as late as } \\
6 \mathrm{~h}\end{array}$ & 10 \\
\hline Brain & $\begin{array}{l}\text { Phase II trial stroke in the } \\
\text { territory of the MCA }\end{array}$ & Human & $\begin{array}{l}\text { Enrollment up to } 8 \mathrm{~h} \text {; mean } 5.5 \mathrm{~h} 3 \\
\text { daily i.v. doses }\end{array}$ & $\begin{array}{l}\text { Significant improvement in clinical } \\
\text { scores and outcome }\end{array}$ & 80 \\
\hline Brain & Blunt trauma & Mouse & Closed impact. Single i.p. dose & $\begin{array}{l}\text { Reduced cavitation volume and } \\
\text { inflammation } 7-10 \text { days later }\end{array}$ & 10 \\
\hline Brain & $\begin{array}{l}\text { Experimental autoimmune } \\
\text { encephalitis }\end{array}$ & Rat & $\begin{array}{l}\text { Female Lewis rat. Multiple dosing } \\
\text { i.p. beginning at day } 3 \text { following } \\
\text { antigen injection }\end{array}$ & $\begin{array}{l}\text { Marked reduction in clinical score } \\
\text { and reduced inflammatory } \\
\text { cytokine levels }\end{array}$ & 10 \\
\hline Brain & Subarrachnoid hemorrhage & Rabbit & $\begin{array}{l}\text { Autologous blood injection into } \\
\text { cisterna magna. Single i.p. dose }\end{array}$ & Virtually complete protection & 85 \\
\hline Brain & $\begin{array}{l}\text { Neonatal hypoxia- } \\
\text { ischemia }\end{array}$ & Rat & $\begin{array}{l}\text { Carotid occlusion and brief } \\
\text { hypoxia. Single i.p. dose }\end{array}$ & $\begin{array}{l}\text { Markedly reduced infarct volume, } \\
\text { reduced apoptosis, reduced NF- } \\
\text { kB and caspase- } 3 \text { in neurons }\end{array}$ & 86 \\
\hline Brain & Ischemia & Rat & $\begin{array}{l}\text { Three-vessel occlusion. Single i.p. } \\
\text { dose }\end{array}$ & Decreased inflammation & 40 \\
\hline Brain & Ischemia & Gerbil & Carotid artery occlusion. & $\begin{array}{l}\text { Reduced apptosis in CA induced } \\
B_{c} X_{L}\end{array}$ & 62 \\
\hline Brain & $\begin{array}{l}\text { Neonatal hypoxia- } \\
\text { ischemia }\end{array}$ & Mouse & $\begin{array}{l}\text { Carotid artery occlusion and brief } \\
\text { hypoxia. Single i.p. dose }\end{array}$ & $\begin{array}{l}\text { Markedly reduced infarct volume, } \\
\text { reduced apoptosis, reduced NF- } \\
\text { kB and caspase- } 3 \text { in neurons }\end{array}$ & 68 \\
\hline Brain & $\begin{array}{l}\text { Hypothermic circulatory } \\
\text { arrest }\end{array}$ & Pig & Hypothermia. Single i.v. dose & $\begin{array}{l}\text { Reduced apoptosis and glutamate } \\
\text { concentrations. }\end{array}$ & 87 \\
\hline Brain & Parkinson & Mice & $\begin{array}{l}\text { 1-methyl-4-phenyl-1,2,3,6- } \\
\text { tetrahydropyridine }\end{array}$ & $\begin{array}{l}\text { Survival of nigral dopaminergic } \\
\text { neurons }\end{array}$ & 88 \\
\hline Brain & Kainate toxicity & Mouse & $\begin{array}{l}\text { Seizures caused by kainic acid. } \\
\text { Single i.p. dose }\end{array}$ & $\begin{array}{l}\text { Pretreatment markedly reduces } \\
\text { seizure severity }\end{array}$ & 10 \\
\hline Brain & MK801 toxicity & Rat & $\begin{array}{l}\text { Newborns given MK801 with a } \\
\text { single dose of EPO }\end{array}$ & Reduction of neuronal apoptosis & 65 \\
\hline Retina & Ischemia/reperfusion & Rat & $\begin{array}{l}\text { Increased intraocular pressure } \\
\text { above aortic. Single ip dose }\end{array}$ & $\begin{array}{l}\text { ERG and histology nearly normal } \\
\text { for } 45 \text { minutes ischemia }\end{array}$ & 89 \\
\hline Spinal cord & Ischemia/reperfusion & Rabbit & $\begin{array}{l}\text { Transient occlusion of the } \\
\text { abdominal aorta. Single i.p. dose }\end{array}$ & $\begin{array}{l}\text { Normal neurological function; } \\
\text { decreased motoneuron apoptosis }\end{array}$ & 90 \\
\hline Spinal cord & Compression & Rat & $\begin{array}{l}\text { Application of aneurysm clip for } \\
1 \text { min. Single and multiple i.v. } \\
\text { doses }\end{array}$ & $\begin{array}{l}\text { Single, multiple doses lead to } \\
\text { marked neurological recovery }\end{array}$ & 91 \\
\hline Sciatic nerve & Compression & Rat & Aneurysm clip. Multiple iv doses & $\begin{array}{l}\text { Attenuated injury and faster } \\
\text { recovery of function }\end{array}$ & 81 \\
\hline $\begin{array}{l}\text { Peripheral } \\
\text { nerve }\end{array}$ & Compression & Rat & Crush; daily s.c. doses & $\begin{array}{l}\text { Decreased pain; less DRG } \\
\text { apoptosis }\end{array}$ & 66 \\
\hline $\begin{array}{l}\text { Peripheral } \\
\text { nerve }\end{array}$ & Diabetic neuropathy & Rat & Streptozotocin; chronic i.p. dosing & $\begin{array}{l}\text { Decreased nociceptive alterations; } \\
\text { restored NCV }\end{array}$ & 92 \\
\hline Heart & Ischemia/reperfusion & Rat & $\begin{array}{l}\text { Occlusion of main coronary artery } \\
\text { for } 45 \mathrm{~min} \text {. Multiple i.p. doses }\end{array}$ & $\begin{array}{l}\text { Less cardiomyocyte loss and } \\
\text { preserved ventricular function }\end{array}$ & 12 \\
\hline Heart & $\begin{array}{l}\text { Preservation of function } \\
\text { isolated heart }\end{array}$ & Mouse & Single i.p. dose & $\begin{array}{l}\text { Pretreatment }(24 \mathrm{~h}) \text { protected from } \\
\text { post ischemic injury }\end{array}$ & 72 \\
\hline Kidney & Cisplatinum injury & Rat & $\begin{array}{l}\text { Cisplatinum-induced acute renal } \\
\text { failure. Multiple i.p. doses }\end{array}$ & Enhanced rate of recovery & 75 \\
\hline Kidney & Ischemia/reperfusion & Rat & Single pretreatment i.p. dose & $\begin{array}{l}\text { Reduced tubular apoptosis and } \\
\text { increased proximal tubular mitosis }\end{array}$ & 73 \\
\hline Skin & Wound healing; ischemia & Rat & $\begin{array}{l}\text { Random skin flap } \\
\text { revascularization. Multiple s.c. } \\
\text { doses }\end{array}$ & $\begin{array}{l}\text { Improved wound healing and } \\
\text { reduced inflammatory response }\end{array}$ & 76,77 \\
\hline Intestine & Hypoxia/reoxygenation & Rat & $\begin{array}{l}\text { Necrotizing enterocolitis. Multiple } \\
\text { i.p. doses }\end{array}$ & Decreased lipid peroxidation & 93,94 \\
\hline
\end{tabular}

penumbral (at risk) region surrounding injury. Study has shown that following the induction, this region is characterized by an increased resistance to subsequent stressors.

These activities in vivo appear to depend upon several processes. In many of these models, diverse pathogenic components play a role, including neuronal death, inflammation and, in the recovery phase, neurorepair. In some cases, the primary mechanism of action of EPO is represented by neuroprotection, while in other models (e.g., experimental autoimmune encephalitis) it could be due to reduced neuroinflammation. We have listed in Table 1 some of the in vitro models where EPO shows neuroprotective effects. It can be seen that, in most models, inhibition of cellular apoptosis was documented. In contrast to its antiapoptotic effect, EPO has not shown any activity in preventing necrosis in either the nervous system (Sinor and Greenberg ${ }^{35}$ and Mennini et al., unpublished) or the heart. ${ }^{12}$

The EPO/EPOR is highly prominent during fetal development, ${ }^{36}$ with the very high levels of expression found in many tissues diminishing rapidly after birth to the generally low levels found in the adult. Gene knockout experiments ${ }^{37}$ have suggested the importance of this system in development, as 


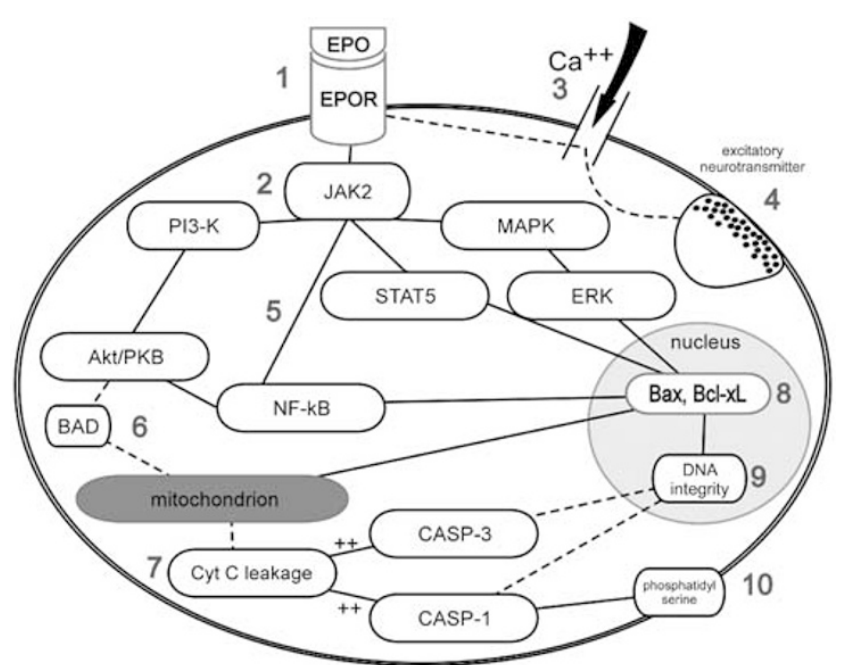

Figure 1 Summary of demonstrated EPO-signaling pathways in neuronal protection, binding of EPO to its receptor (1) leads to phosphorylation of janus kinase 2 (2). This subsequently activates multiple cascades recruiting PI3-K, Stat5 and MAPKinase. Further, flux of $\mathrm{Ca}^{2+}$ through voltage sensitive channels is modulated (generally inhibited (3)), affecting neurotransmitter release and therefore neuronal excitability (4). NF-kB is reported to be dually activated by JAK-2 and by Akt (5). The net effect is a reduction in the proapoptotic protein $\operatorname{BAD}(6)$, and therefore the probability of mitochondrial leakage of cytochrome $C$ (7), an increased production of antiapoptotic proteins of the Bcl-x family (8) and ultimate preservation of the DNA integrity (9). To the extent cytochrome $C$ leakage is not prevented, caspase activation also occurs, inducing DNA degradation and the externalization of phosphatidyl serine on the cell membrane (10), promoting the activation of the inflammatory cells. Solid lines indicate activation; dashed indicate inhibition

the embryos of EPOR -/- animals have abnormal brain development characterized by decreased neuronal progenitor cells as well as grossly decreased neuronal densities associated with massive neuronal apoptosis. Additionally, the heart is underdeveloped. On the other hand, erythroidspecific expression of EPOR in EPOR knockout mice rescues them from lethality suggesting that nonhematopoietic EPOR is not essential for development. ${ }^{38}$ It would be interesting to evaluate these mice in models of tissue injury.

\section{EPO affects the interaction between apoptosis and inflammation}

In many in vivo models of CNS disease for which EPO shows a protective effect, inflammation is also an important pathogenic component, induced by production of cytokines and chemokines followed by leukocyte infiltration and glial activation and proliferation. The complicated inter-related protective effects initiated by EPO administration have been examined in some detail in experimental stroke in the rat. Using a model of ischemia with reperfusion, it was shown that neurons within the penumbra would undergo apoptosis unless exposed to EPO within $3 \mathrm{~h}$ of injury. ${ }^{39}$ In addition to this antiapoptotic effect, EPO administration is also associated with a marked decrease in proinflammatory cytokines within the hemisphere undergoing infarction. ${ }^{40}$ This profoundly reduced the activation of astrocytes within the region (as indicated by increased glial fibrillary acidic protein (GFAP) expression) as well as grossly decreased influx of inflamma- tory microglia. The marked in vivo reduction of recruitment of microglia into the region of injury is likely explained by the reduced expression of cell surface markers of apoptosis, for example, phosphatidylserine. ${ }^{41}$ It should be noted that this proinflammatory role of phosphatidylserine conflicts with other works showing that it stimulates phagocytosis but not inflammation - rather anti-inflammation (for instance: Chan et al., ${ }^{42}$ De Simone et al. ${ }^{43}$ and Brouckaert et al. $\left.{ }^{44}\right)$ ).

Using an in vitro system of neurons cocultured with glia, Villa et al. ${ }^{40}$ have shown that the anti-inflammatory effects of EPO do not arise from a direct antagonism or a reduction of proinflammatory cytokines, but rather by an antiapoptotic effect on neurons. In fact, neurons exposed to trimethyltin, a toxin that induces neuronal apoptosis, ${ }^{45}$ release as yet unidentified factors that stimulate inflammatory TNF production by glial cells that, in turn, amplifies neurotoxicity. ${ }^{46}$ In this context, EPO inhibits TNF production by TMT-exposed neuron-glia co-cultures but not by pure glial preparations directly exposed to neuronal products or LPS. ${ }^{40}$ This pathway of 'anti-inflammation by neuroprotection' is outlined in Figure 2.

According to a well-accepted scheme, apoptosis is a way of dying that triggers much less inflammation than by necrosis, and this is certainly true in many experimental models. ${ }^{47,48}$ However, this model of 'docking without shocking', ${ }^{49}$ may not apply to all pathological conditions, and production of inflammatory cytokines by tissue macrophages during phagocytosis of apoptotic cells. ${ }^{50,51}$ Similarly to what is observed in a model of cerebral ischemia with EPO, ${ }^{40}$ inhibition of apoptosis by lysophosphatidic acid or caspase inhibitors decreases inflammation in models of ischemic injury in the kidney and the brain. ${ }^{52,53}$

It should be noted, however, that an anti-inflammatory effect of EPO was demonstrated in a model of experimental autoimmune encephalomyelitis, an inflammatory pathology of the CNS of autoimmune origin with marked inflammation in the almost complete absence of neuronal death, at least in the earliest times of the disease. ${ }^{54}$ Thus, it cannot be ruled out that EPO exerts an anti-inflammatory action on the CNS by different mechanisms than those depicted in Figure 2, although it is presently unclear what these mechanisms may be.

\section{EPO signaling in nervous system cells}

EPO has been shown to have multiple effects on neurons. Activation of the EPOR modulates $\mathrm{Ca}^{2+}$ influx ${ }^{55,56}$ in vitro. Inhibition of $\mathrm{Ca}^{2+}$ influx upon depolarization directly reduces synaptic vesicle release of glutamate, which acts to reduce the magnitude of neuronal injury (Figure 1). In addition, it could explain the effects of EPO in reducing seizure severity ${ }^{10}$ as well as reported effects on learning and memory. ${ }^{57}$ Other indirect effects of EPO that reduce neuronal injury have also been delineated. For example, EPO treatment increases astrocyte production of glutathione peroxidase and in this manner ameliorates neuronal damage caused by excitotoxins. ${ }^{58}$ EPO also promotes the differentiation and maturation of astrocytes and oligodendrocytes and directly induces the proliferation of astrocytes, ${ }^{59}$ actions that can modify potential 


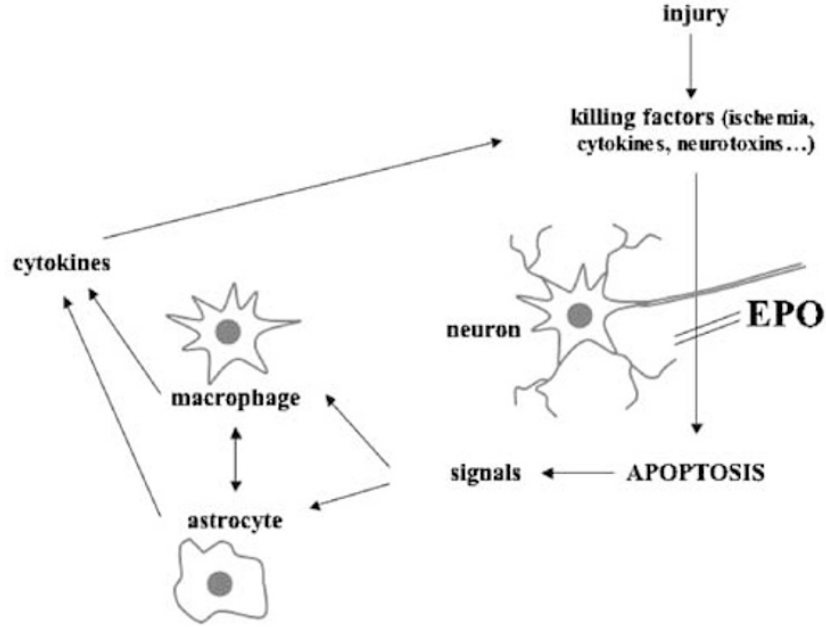

Figure 2 Interplay between the antiapoptotic action of EPO and neuroinflammation

injury. Undoubtedly, other indirect neuronal protection functions remain to be described.

Several antiapoptotic pathways regulated by EPO in erythroid precursors are also activated in neurons and may play a role in prevention of neuronal apoptosis. Triggering NF$k B$ via activated Jak2 has been reported, and the antiapoptotic action of EPO on nitric oxide-induced cortical neuron apoptosis is blocked by inhibitors of NF-kB translocation as well as by overexpression of an IkBalpha super-repressor or of a dominant interfering form of Jak2. ${ }^{60}$ The antiapoptotic action of NF-kB in neurons also involves activation of Akt1 and Bad phosphorylation ${ }^{41,61}$ as well as Bcl-xL upregulation. ${ }^{62,63}$ $\mathrm{Bcl}-\mathrm{xL}$ was also found induced by EPO in a study where DNA microarrays were used to identify modulated genes in PC12 neuronal-like cells ${ }^{64}$ and in vivo in a gerbil model of cerebral ischemia. ${ }^{62}$

Of note, Ruscher et al., ${ }^{61}$ studying the protective effect of EPO against oxygen glucose deprivation-induced apoptosis of primary cortical neurons, confirmed that the protective effect requires Jak2, as shown by Digicaylioglu and Lipton, ${ }^{60}$ and of $\mathrm{PI}(3)$ Kinase, as shown by us, ${ }^{39}$ using specific inhibitors of these kinases. In particular, the MAPK inhibitor PD98059 and the $\mathrm{PI}(3)$ Kinase inhibitor LY984002 blocked the protective effect of EPO in hippocampal neurons exposed to hypoxia. ${ }^{39}$ On the other hand, unlike others reported in erythroid cells, the other pathway downstream of Jak2, activation of STATs, was not activated by EPO in this study, and no induction of mRNA for Bcl2, Bcl-xL, Bag-1, Bax or Bad, was observed, as measured by PCR. ${ }^{61}$

In addition to directly activating survival kinases such as ERK, EPO, while not activating Akt under normal conditions, prevents the decrease in Akt phosphorylation induced by a 15-h exposure of neurons to hypoxia. ${ }^{39} \mathrm{~A}$ similar pattern has been recently observed in vivo where administration of EPO, protects newborn rats from neuronal apoptosis induced by MK801 and prevents MK801-induced decrease in the phosphorylation level of ERK1/2 and Akt. ${ }^{65}$

EPO has profound effects in reducing injury and enhancing recovery in compression injuries of peripheral nerves. ${ }^{66,67}$
Campana et al. ${ }^{66,67}$ performed a crush injury of a spinal nerve root for which follow-up showed a robust effect by EPO to prevent apoptosis in dorsal root ganglion neurons which occurred by Jak2 signaling, as well as a corresponding improvement in pain behavior.

Clearly, the relevance of the pathways outlined above in the neuroprotection observed in vivo with EPO is far from being established. For instance, in a study of neonatal hypoxic ischemic injury in mice has reported that NF-kB-immunoreactivity in neurons in the injured areas was not decreased by EPO, neither was its subcellular distribution, despite a marked neuroprotective effect. ${ }^{68}$

\section{Other tissue-protective activities of EPO}

Capillary endothelial cells express EPOR on their intraluminal surfaces. EPO has been shown in vitro to antagonize the apoptosis of endothelial cells subjected to ischemic stressors. ${ }^{69}$ EPO thus plays a role in maintaining the integrity of the microvasculature. Additionally, EPO has also been shown to stimulate mitogenesis and support angiogenesis, both functioning to improve tissue oxygenation. The endothelial cell is additionally important as a conduit for systemically administered EPO to pass into organs with a barrier to the circulation. Recent in vitro studies have shown that EPO present on the apical (luminal) side is transported in a unidirectional manner through the endothelial cell by transcytosis. ${ }^{70}$ Further, EPO strengthens the tight junctions of endothelial cells and will antagonize the effects of VEGF, which is known to reduce tight junction proteins allowing leakage from the capillary around the endothelial cells into the brain parenchyma. ${ }^{70}$

EPO has been shown to be protective of myocardial ischemia either permanent or with reperfusion. ${ }^{12,71}$ Further, cardiomyocytes losses were not completely prevented in EPO-treated animals, being reduced by $\sim 50 \%$. In spite of tissue loss, maladaptive remodeling did not occur, resulting in a maintained normal cardiac function. ${ }^{12}$ Further, studies performed on isolated hearts have shown that EPO mediates ischemic preconditioning. ${ }^{72}$

The kidney is protected by EPO in the setting of both ischemic and toxic injuries. ${ }^{73-75}$ In ischemic injury with reperfusion, EPO prevents apoptosis of tubular epithelial cells as well as mediates intense mitotic activity of the surviving population of proximal tubular epithelial cells. ${ }^{73}$

The skin has also been shown to be protected by EPO in rodent flap models. ${ }^{76,77}$ In these studies, the tissue-protective effects appear to depend strongly on the dose and treatment duration, suggesting that tissues may vary in their responses to EPO.

From the perspective of the evolving concept of EPO and EPOR as a endogenous local system of protection and the widespread expression of these molecules, it is likely that many other organs and tissues when examined for protective effects of EPO will demonstrate a positive role.

\section{Therapeutic perspectives}

Recombinant human EPO has been shown in general to be an exceedingly safe drug, as millions of patients have received it over the last decade for treatment of anemia. However, some 
side effects, including increased blood pressure and risk of thrombosis have been noted and these are of special concern for patients who are not anemic. EPO has been shown to mediate angiogenesis in the microcirculation, with a potency similar to VEGF. ${ }^{78}$ However, unlike VEGF, EPO does not reduce the tight junctions between endothelial cells, and therefore does not promote capillary leakage. ${ }^{70}$

The experimental models characterized by potential cellular barriers for the systemic administration of recombinant human EPO (e.g., brain, retina, spinal cord) have been found to require a minimum effective dose that is generally higher than the doses of EPO currently employed for treatment of anemia (but those used experimentally for bone marrow rescue have been much higher, as reviewed by Baron et al. $\left.{ }^{79}\right)$. Although acute (i.e. a few doses) administration of recombinant human EPO for treatment of tissue injury is not likely to be harmful, chronic dosing will at the least provoke increases in erythrocyte mass. This is undesirable from a rheologically perspective and could worsen injury. The recent Phase II trial of human stroke by EPO used three daily doses substantially higher than the clinical norm and, in these patients, EPO was shown to be safe and did not raise the hemoglobin concentration. ${ }^{80}$ Thus, this might represent a valuable therapeutic approach to acute CNS injury, such as brain and spinal cord trauma. On the other hand, use of EPO in chronic diseases associated with neuronal apoptosis or neuroinflammation, such as Parkinson's disease, Alzheimer disease or multiple sclerosis would be possible only if the erythropoietic effect was blocked.

The studies on the signaling mechanisms of the cytoprotective versus the hemopoietic actions of EPO, and the receptors involved, will help identifying molecules that retain the cytoprotective actions of EPO but not its hemopoietic effects. It was recently reported that desialylated EPO is a neuroprotective cytokine that does not induce erythrodifferentiation, ${ }^{81}$ indicating the feasibility of this approach.

In summary, EPO is a major modifier of apoptosis of multiple cell types in different tissues and organs in the setting of potential injury. However, EPO also exhibits many other actions that serve to protect cells either directly or indirectly. EPO should therefore be regarded also as a general tissueprotective cytokine.

\section{References}

1. Semenza GL (2001) HIF-1 and mechanisms of hypoxia sensing. Curr. Opin. Cell Biol. 13: 167-171

2. Wiesener MS and Maxwell PH (2003) HIF and oxygen sensing; as important to life as the air we breathe? Ann. Med. 35: 183-190

3. Wenger RH (2002) Cellular adaptation to hypoxia: 02-sensing protein hydroxylases, hypoxia-inducible transcription factors, and O2-regulated gene expression. FASEB J. 16: 1151-1162

4. Seagroves TN, Ryan HE, Lu H, Wouters BG, Knapp M, Thibault $P$, Laderoute $\mathrm{K}$ and Johnson RS (2001) Transcription factor HIF-1 is a necessary mediator of the pasteur effect in mammalian cells. Mol. Cell Biol. 21: 3436-3444

5. Minchenko A, Leshchinsky I, Opentanova I, Sang N, Srinivas V, Armstead V and Caro J (2002) Hypoxia-inducible factor-1-mediated expression of the 6phosphofructo-2-kinase/fructose-2,6-bisphosphatase-3 (PFKFB3) gene. Its possible role in the Warburg effect. J. Biol. Chem. 277: 6183-6187
6. Zaman K, Ryu H, Hall D, O'Donovan K, Lin KI, Miller MP, Marquis JC, Baraban JM, Semenza GL and Ratan RR (1999) Protection from oxidative stressinduced apoptosis in cortical neuronal cultures by iron chelators is associated with enhanced DNA binding of hypoxia-inducible factor-1 and ATF-1/CREB and increased expression of glycolytic enzymes, p21(waf1/cip1), and erythropoietin. J. Neurosci. 19: 9821-9830

7. Lambrechts D, Storkebaum E, Morimoto M, Del-Favero J, Desmet F, Marklund SL, Wyns S, Thijs V, Andersson J, van Marion I, Al-Chalabi A, Bornes S, Musson R, Hansen V, Beckman L, Adolfsson R, Pall HS, Prats H, Vermeire S, Rutgeerts P, Katayama S, Awata T, Leigh N, Lang-Lazdunski L, Dewerchin M, Shaw C, Moons L, Vlietinck R, Morrison KE, Robberecht W, Van Broeckhoven C, Collen D, Andersen PM and Carmeliet P (2003) VEGF is a modifier of amyotrophic lateral sclerosis in mice and humans and protects motoneurons against ischemic death. Nat. Genet. 34: 383-394

8. Oosthuyse B, Moons L, Storkebaum E, Beck H, Nuyens D, Brusselmans K, Van Dorpe J, Hellings P, Gorselink M, Heymans S, Theilmeier G, Dewerchin M, Laudenbach V, Vermylen P, Raat H, Acker T, Vleminckx V, Van Den Bosch L, Cashman N, Fujisawa H, Drost MR, Sciot R, Bruyninckx F, Hicklin DJ, Ince C, Gressens P, Lupu F, Plate KH, Robberecht W, Herbert JM, Collen D and Carmeliet $P$ (2001) Deletion of the hypoxia-response element in the vascular endothelial growth factor promoter causes motor neuron degeneration. Nat. Genet. 28: 131-138

9. Sun Y, Jin K, Xie L, Childs J, Mao XO, Logvinova A and Greenberg DA (2003) VEGF-induced neuroprotection, neurogenesis, and angiogenesis after focal cerebral ischemia. J. Clin. Invest. 111: 1843-1851

10. Brines ML, Ghezzi P, Keenan S, Agnello D, de Lanerolle NC, Cerami C, Itri LM and Cerami A (2000) Erythropoietin crosses the blood-brain barrier to protect against experimental brain injury. Proc. Natl. Acad. Sci. USA 97: 10526-10531

11. Ehrenreich $H$, Degner D, Meller J, Brines M, Behe M, Hasselblatt M, Woldt $H$, Falkai P, Knerlich F, Jacob S, von Ahsen N, Maier W, Bruck W, Ruther E, Cerami A, Becker W and Siren AL (2004) Erythropoietin: a candidate compound for neuroprotection in schizophrenia. Mol. Psychiatry. 9: 42-54

12. Calvillo L, Latini R, Kajstura J, Leri A, Anversa P, Ghezzi P, Salio M, Cerami A and Brines M (2003) Recombinant human erythropoietin protects the myocardium from ischemia-reperfusion injury and promotes beneficial remodeling. Proc. Natl. Acad. Sci. USA 100: 4802-4806

13. Boyer SH, Bishop TR, Rogers OC, Noyes AN, Frelin LP and Hobbs S (1992) Roles of erythropoietin, insulin-like growth factor 1 , and unidentified serum factors in promoting maturation of purified murine erythroid colony-forming units. Blood 80: 2503-2512

14. Koury MJ and Bondurant MC (1988) Maintenance by erythropoietin of viability and maturation of murine erythroid precursor cells. J. Cell Physiol. 137: 65-74

15. Miller CP, Liu ZY, Noguchi CT and Wojchowski DM (1999) A minimal cytoplasmic subdomain of the erythropoietin receptor mediates erythroid and megakaryocytic cell development. Blood 94: 3381-3387

16. Spivak JL, Pham T, Isaacs M and Hankins WD (1991) Erythropoietin is both a mitogen and a survival factor. Blood 77: 1228-1233

17. Yu H, Bauer B, Lipke GK, Phillips RL and Van Zant G (1993) Apoptosis and hematopoiesis in murine fetal liver. Blood 81: 373-384

18. Koury MJ and Bondurant MC (1990) Erythropoietin retards DNA breakdown and prevents programmed death in erythroid progenitor cells. Science 248: 378-381

19. Silva M, Grillot D, Benito A, Richard C, Nunez G and Fernandez-Luna JL (1996) Erythropoietin can promote erythroid progenitor survival by repressing apoptosis through Bcl-XL and Bcl-2. Blood 88: 1576-1582

20. Wagner KU, Claudio E, Rucker III EB, Riedlinger G, Broussard C, Schwartzberg PL, Siebenlist U and Hennighausen L (2000) Conditional deletion of the Bcl-x gene from erythroid cells results in hemolytic anemia and profound splenomegaly. Development 127: 4949-4958

21. Bazan JF (1989) A novel family of growth factor receptors: a common binding domain in the growth hormone, prolactin, erythropoietin and IL-6 receptors, and the p75 IL-2 receptor beta-chain. Biochem. Biophys. Res. Commun. 164: 788-795

22. Bazan JF (1990) Structural design and molecular evolution of a cytokine receptor superfamily. Proc. Natl. Acad. Sci. USA 87: 6934-6938

23. Wojchowski DM, Gregory RC, Miller CP, Pandit AK and Pircher TJ (1999) Signal transduction in the erythropoietin receptor system. Exp. Cell Res. 253: 143-156 
24. Livnah O, Stura EA, Middleton SA, Johnson DL, Jolliffe LK and Wilson IA (1999) Crystallographic evidence for preformed dimers of erythropoietin receptor before ligand activation. Science 283: $987-990$

25. Silva M, Benito A, Sanz C, Prosper F, Ekhterae D, Nunez G and FernandezLuna JL (1999) Erythropoietin can induce the expression of bcl-x(L) through Stat5 in erythropoietin-dependent progenitor cell lines. J. Biol. Chem. 274: 22165-22169

26. Socolovsky M, Fallon AE, Wang S, Brugnara C and Lodish HF (1999) Fetal anemia and apoptosis of red cell progenitors in Stat5a-/-5b-/- mice: a direct role for Stat5 in Bcl-X(L) induction. Cell 98: 181-191

27. Kawakami M, Sekiguchi M, Sato K, Kozaki S and Takahashi M (2001) Erythropoietin receptor-mediated inhibition of exocytotic glutamate release confers neuroprotection during chemical ischemia. J. Biol. Chem. 276: 39469-39475

28. Kashii $Y$, Uchida M, Kirito K, Tanaka M, Nishijima K, Toshima M, Ando T, Koizumi K, Endoh T, Sawada K, Momoi M, Miura Y, Ozawa K and Komatsu N (2000) A member of Forkhead family transcription factor, FKHRL1, is one of the downstream molecules of phosphatidylinositol 3-kinase-Akt activation pathway in erythropoietin signal transduction. Blood 96: 941-949

29. Leverrier Y, Thomas J, Mathieu AL, Low W, Blanquier B and Marvel J (1999) Role of PI3-kinase in Bcl-X induction and apoptosis inhibition mediated by IL-3 or IGF-1 in Baf-3 cells. Cell Death Differ. 6: 290-296

30. Romashkova JA and Makarov SS (1999) NF-kappaB is a target of AKT in antiapoptotic PDGF signalling. Nature 401: 86-90

31. Bernaudin M, Marti HH, Roussel S, Divoux D, Nouvelot A, MacKenzie ET and Petit $E$ (1999) A potential role for erythropoietin in focal permanent cerebral ischemia in mice. J. Cereb. Blood Flow Metab. 19: 643-651

32. Eid T, Brines ML, Cerami A, Spencer DD, Kim JH, Schweitzer JS, Ottersen OP and de Lanerolle NC (2004) Increased expression of erythropoietin receptor on blood vessels in the human epileptogenic hippocampus with sclerosis. $\mathrm{J}$ Neuropathol. Exp. Neurol. 63: 73-83

33. Siren AL, Knerlich F, Poser W, Gleiter CH, Bruck W and Ehrenreich H (2001) Erythropoietin and erythropoietin receptor in human ischemic/hypoxic brain Acta Neuropathol. (Berl.) 101: 271-276

34. Nagai A, Nakagawa E, Choi HB, Hatori K, Kobayashi S and Kim SU (2001) Erythropoietin and erythropoietin receptors in human CNS neurons, astrocytes, microglia, and oligodendrocytes grown in culture. J. Neuropathol. Exp. Neurol. 60: 386-392

35. Sinor AD and Greenberg DA (2000) Erythropoietin protects cultured cortical neurons, but not astroglia, from hypoxia and AMPA toxicity. Neurosci, Lett. 290: 213-215

36. Juul SE, Yachinis AT, Rojiani AM and Christensen RD (1999) Immunohistochemical Localization of Erythropoietin and Its Receptor in the Developing Human Brain. Pediat. Dev. Pathol. 2: 148-158

37. Yu X, Shacka JJ, Eells JB, Suarez-Quian C, Przygodzki RM, Beleslin-Cokic B, Lin CS, Nikodem VM, Hempstead B, Flanders KC, Costantini F and Noguchi CT (2002) Erythropoietin receptor signalling is required for normal brain development. Development 129: 505-516

38. Suzuki N, Ohneda O, Takahashi S, Higuchi M, Mukai HY, Nakahata T, Imagawa $S$ and Yamamoto M (2002) Erythroid-specific expression of the erythropoietin receptor rescued its null mutant mice from lethality. Blood 100 2279-2288

39. Siren AL, Fratelli M, Brines M, Goemans C, Casagrande S, Lewczuk P, Keenan S, Gleiter C, Pasquali C, Capobianco A, Mennini T, Heumann R, Cerami A, Ehrenreich $\mathrm{H}$ and Ghezzi $\mathrm{P}$ (2001) Erythropoietin prevents neuronal apoptosis after cerebral ischemia and metabolic stress. Proc. Natl. Acad. Sci. USA 98: 4044-4049

40. Villa $P$, Bigini $P$, Mennini $T$, Agnello $D$, Laragione $T$, Cagnotto $A$, Viviani $B$, Marinovich M, Cerami A, Coleman TR, Brines M and Ghezzi P (2003) Erythropoietin selectively attenuates cytokine production and inflammation in cerebral ischemia by targeting neuronal apoptosis. J. Exp. Med. 198: 971-975

41. Chong ZZ, Kang JQ and Maiese K (2003) Erythropoietin fosters both intrinsic and extrinsic neuronal protection through modulation of microglia, Akt1, Bad, and caspase-mediated pathways. Br. J. Pharmacol. 138: 1107-1118

42. Chan A, Seguin R, Magnus T, Papadimitriou C, Toyka KV, Antel JP and Gold R (2003) Phagocytosis of apoptotic inflammatory cells by microglia and its therapeutic implications: termination of CNS autoimmune inflammation and modulation by interferon-beta. Glia 43: 231-242
43. De Simone R, Ajmone-Cat MA, Tirassa P and Minghetti L (2003) Apoptotic PC12 cells exposing phosphatidylserine promote the production of antiinflammatory and neuroprotective molecules by microglial cells. J. Neuropathol. Exp. Neurol. 62: 208-216

44. Brouckaert G, Kalai M, Krysko DV, Saelens X, Vercammen D, Ndlovu, Haegeman G, D'Herde K and Vandenabeele P (2004) Phagocytosis of necrotic cells by macrophages is phosphatidylserine dependent and does not induce inflammatory cytokine production. Mol. Biol. Cell. 15: 1089-1100

45. Viviani $B$, Rossi AD, Chow SC and Nicotera $P$ (1995) Organotin compounds induce calcium overload and apoptosis in PC12 cells. Neurotoxicology 16: $19-25$

46. Viviani B, Corsini E, Galli CL and Marinovich M (1998) Glia increase degeneration of hippocampal neurons through release of tumor necrosis factoralpha. Toxicol. Appl. Pharmacol. 150: 271-276

47. Henson PM, Bratton DL and Fadok VA (2001) The phosphatidylserine receptor: a crucial molecular switch? Nat. Rev. Mol. Cell Biol. 2: 627-633

48. Devitt A, Moffatt OD, Raykundalia C, Capra JD, Simmons DL and Gregory CD (1998) Human CD14 mediates recognition and phagocytosis of apoptotic cells. Nature 392: 505-509

49. Savill J (1998) Apoptosis. Phagocytic docking without shocking. Nature 392: $442-443$

50. Kurosaka K, Watanabe N and Kobayashi $\mathrm{Y}$ (2001) Production of proinflammatory cytokines by resident tissue macrophages after phagocytosis of apoptotic cells. Cell Immunol. 211: 1-7

51. Canbay A, Feldstein AE, Higuchi H, Werneburg N, Grambihler A, Bronk SF and Gores GJ (2003) Kupffer cell engulfment of apoptotic bodies stimulates death ligand and cytokine expression. Hepatology 38: 1188-1198

52. de Vries B, Matthijsen RA, van Bijnen AA, Wolfs TG and Buurman WA (2003) Lysophosphatidic acid prevents renal ischemia-reperfusion injury by inhibition of apoptosis and complement activation. Am. J. Pathol. 163: 47-56

53. Rabuffetti M, Sciorati C, Tarozzo G, Clementi E, Manfredi AA and Beltramo M (2000) Inhibition of caspase-1-like activity by Ac-Tyr-Val-Ala-Asp-chloromethyl ketone induces long-lasting neuroprotection in cerebral ischemia through apoptosis reduction and decrease of proinflammatory cytokines. J. Neurosci. 20: $4398-4404$

54. Agnello $D$, Bigini $P$, Villa $P$, Mennini $T$, Cerami $A$, Brines $M L$ and Ghezzi P (2002) Erythropoietin exerts an anti-inflammatory effect on the CNS in a model of experimental autoimmune encephalomyelitis. Brain Res. 952: 128-134

55. Kawakami M, Iwasaki S, Sato K and Takahashi M (2000) Erythropoietin inhibits calcium-induced neurotransmitter release from clonal neuronal cells. Biochem. Biophys. Res. Commun. 279: 293-297

56. Masuda S, Nagao M, Takahata K, Konishi Y, Gallyas Jr. F, Tabira T and Sasaki R (1993) Functional erythropoietin receptor of the cells with neural characteristics. Comparison with receptor properties of erythroid cells. J. Biol. Chem. 268: 11208-11216

57. Mogensen J, Miskowiak K, Sorensen TA, Lind CT, Olsen NV, Springborg JB and Mala $\mathrm{H}$ (2004) Erythropoietin improves place learning in fimbria-fornixtransected rats and modifies the search pattern of normal rats. Pharmacol. Biochem. Behav. 77: 381-390

58. Genc S, Akhisaroglu M, Kuralay F and Genc K (2002) Erythropoietin restores glutathione peroxidase activity in 1-methyl-4- phenyl-1,2,5,6tetrahydropyridine-induced neurotoxicity in C57BL mice and stimulates murine astroglial glutathione peroxidase production in vitro. Neurosci. Lett. 321: $73-76$

59. Sugawa M, Sakurai Y, Ishikawa-leda Y, Suzuki H and Asou H (2002) Effects of erythropoietin on glial cell development; oligodendrocyte maturation and astrocyte proliferation. Neurosci. Res. 44: 391-403

60. Digicaylioglu M and Lipton SA (2001) Erythropoietin-mediated neuroprotection involves cross-talk between Jak2 and NF-kappaB signalling cascades. Nature 412: $641-647$

61. Ruscher K, Freyer D, Karsch M, Isaev N, Megow D, Sawitzki B, Priller J, Dirnagl $U$ and Meisel A (2002) Erythropoietin is a paracrine mediator of ischemic tolerance in the brain: evidence from an in vitro model. J. Neurosci. 22: 10291-10301

62. Wen TC, Sadamoto Y, Tanaka J, Zhu PX, Nakata K, Ma YJ, Hata R and Sakanaka M (2002) Erythropoietin protects neurons against chemical hypoxia and cerebral ischemic injury by up-regulating $\mathrm{Bcl}-\mathrm{xL}$ expression. J. Neurosci. Res. 67: 795-803 
63. Chong ZZ, Kang JQ and Maiese K (2002) Hematopoietic factor erythropoietin fosters neuroprotection through novel signal transduction cascades. J. Cereb. Blood Flow Metab. 22: 503-514

64. Renzi MJ, Farrell FX, Bittner A, Galindo JE, Morton M, Trinh H and Jolliffe LK (2002) Erythropoietin induces changes in gene expression in PC-12 cells. Brain Res. Mol. Brain Res. 104: 86-95

65. Dzietko M, Felderhoff-Mueser U, Sifringer M, Krutz B, Bittigau P, Thor F, Heumann R, Bührer C, Ikonomidou C and Hansen HH (2004) Erythropoietin protects the developing brain against $\mathrm{N}$-methyl-aspartate receptor antagonist neurotoxicity. Neurobiol. Dis. 15: 177-187

66. Sekiguchi Y, Kikuchi S, Myers RR and Campana WM (2003) ISSLS prize winner: Erythropoietin inhibits spinal neuronal apoptosis and pain following nerve root crush. Spine 28: 2577-2584

67. Campana WM and Myers RR (2003) Exogenous erythropoietin protects against dorsal root ganglion apoptosis and pain following peripheral nerve injury. Eur. J. Neurosci. 18: 1497-1506

68. Matsushita H, Johnston MV, Lange MS and Wilson MA (2003) Protective effect of erythropoietin in neonatal hypoxic ischemia in mice. Neuro Report 14 1757-1761

69. Chong ZZ, Kang JQ and Maiese K (2002) Erythropoietin is a novel vascular protectant through activation of Akt1 and mitochondrial modulation of cysteine proteases. Circulation 106: 2973-2979

70. Martinez-Estrada OM, Rodriguez-Millan E, Gonzalez-De Vicente E, Reina M, Vilaro S and Fabre M (2003) Erythropoietin protects the in vitro blood-brain barrier against VEGF-induced permeability. Eur. J. Neurosci. 18: 2538-2544

71. Moon C, Krawczyk M, Ahn D, Ahmet I, Paik D, Lakatta EG and Talan MI (2003) Erythropoietin reduces myocardial infarction and left ventricular functional decline after coronary artery ligation in rats. Proc. Natl. Acad. Sci. USA 100: $11612-11617$

72. Cai Z, Manalo DJ, Wei G, Rodriguez ER, Fox-Talbot K, Lu H, Zweier JL and Semenza GL (2003) Hearts from rodents exposed to intermittent hypoxia or erythropoietin are protected against ischemia-reperfusion injury. Circulation 108: $79-85$

73. Vesey DA, Cheung C, Pat B, Endre Z, Gobe G and Johnson DW (2004) Erythropoietin protects against ischaemic acute renal injury. Nephrol. Dial. Transplant. 19: 348-355

74. Yang CW, Li C, Jung JY, Shin SJ, Choi BS, Lim SW, Sun BK, Kim YS, Kim J, Chang YS and Bang BK (2003) Preconditioning with erythropoietin protects against subsequent ischemia-reperfusion injury in rat kidney. FASEB J. 17: 1754-1755

75. Bagnis $C$, Beaufils $H$, Jacquiaud $C$, Adabra $Y$, Jouanneau $C$, Le Nahour $G$ Jaudon MC, Bourbouze R, Jacobs C and Deray G (2001) Erythropoietin enhances recovery after cisplatin-induced acute renal failure in the rat. Nephrol. Dial. Transplant. 16: 932-938

76. Buemi M, Vaccaro M, Sturiale A, Galeano MR, Sansotta C, Cavallari V, Floccari F, D'Amico D, Torre V, Calapai G, Frisina N, Guarneri F and Vermiglio G (2002) Recombinant human erythropoietin influences revascularization and healing in a rat model of random ischaemic flaps. Acta Derm. Venereol. 82: 411-417

77. Saray A, Ozakpinar R, Koc C, Serel S, Sen Z and Can Z (2003) Effect of chronic and short-term erythropoietin treatment on random flap survival in rats: an experimental study. Laryngoscope 113: 85-89

78. Jaquet K, Krause K, Tawakol-Khodai M, Geidel S and Kuck KH (2002) Erythropoietin and VEGF exhibit equal angiogenic potential. Microvasc. Res. 64: 326-333

79. Baron F, Frere P, Fillet $G$ and Beguin $Y$ (2003) Recombinant human erythropoietin therapy is very effective after an autologous peripheral blood stem cell transplant when started soon after engraftment. Clin. Cancer Res. 9: 5566-5572
80. Ehrenreich H, Hasselblatt M, Dembowski C, Cepek L, Lewczuk P, Stiefel M, Rustenbeck HH, Breiter N, Jacob S, Knerlich F, Bohn M, Poser W, Ruther E, Kochen M, Gefeller O, Gleiter C, Wessel TC, De Ryck M, Itri L, Prange H, Cerami A, Brines M and Siren AL (2002) Erythropoietin therapy for acute stroke is both safe and beneficial. Mol. Med. 8: 495-505

81. Erbayraktar S, Grasso G, Sfacteria A, Xie QW, Coleman T, Kreilgaard M, Torup L, Sager T, Erbayraktar Z, Gokmen N, Yilmaz O, Ghezzi P, Villa P, Fratelli M, Casagrande S, Leist M, Helboe L, Gerwein J, Christensen S, Geist MA, Pedersen LO, Cerami-Hand C, Wuerth JP, Cerami A and Brines M (2003) Asialoerythropoietin is a nonerythropoietic cytokine with broad neuroprotective activity in vivo. Proc. Natl. Acad. Sci. USA 100: 6741-6746

82. Koshimura K, Murakami Y, Sohmiya M, Tanaka J and Kato Y (1999) Effects of erythropoietin on neuronal activity. J. Neurochem. 72: 2565-2572

83. Morishita E, Masuda S, Nagao M, Yasuda Y and Sasaki R (1997) Erythropoietin receptor is expressed in rat hippocampal and cerebral cortical neurons, and erythropoietin prevents in vitro glutamate-induced neuronal death. Neuroscience 76 : 105-116

84. Sakanaka M, Wen TC, Matsuda S, Masuda S, Morishita E, Nagao M and Sasaki R (1998) In vivo evidence that erythropoietin protects neurons from ischemic damage. Proc. Natl. Acad. Sci. USA 95: 4635-4640

85. Grasso G (2001) Neuroprotective effect of recombinant human erythropoietin in experimental subarachnoid hemorrhage. J. Neurosurg. Sci. 45: 7-14

86. Kumral A, Ozer E, Yilmaz O, Akhisaroglu M, Gokmen N, Duman N, Ulukus C, Genc S and Ozkan H (2003) Neuroprotective effect of erythropoietin on hypoxic-ischemic brain injury in neonatal rats. Biol. Neonate 83: 224-228

87. Romsi P, Ronka E, Kiviluoma K, Vainionpaa V, Hirvonen J, Mennander A, Pokela M, Biancari F, Rimpilainen $\mathrm{J}$ and Juvonen $T$ (2002) Potential neuroprotective benefits of erythropoietin during experimental hypothermic circulatory arrest. J. Thorac. Cardiovasc. Surg. 124: 714-723

88. Genc S, Kuralay F, Genc K, Akhisaroglu M, Fadiloglu S, Yorukoglu K, Fadiloglu $M$ and Gure A (2001) Erythropoietin exerts neuroprotection in 1-methyl-4phenyl-1,2,3,6-tetrahydropyridine-treated C57/BL mice via increasing nitric oxide production. Neurosci. Lett. 298: 139-141

89. Junk AK, Mammis A, Savitz SI, Singh M, Roth S, Malhotra S, Rosenbaum PS, Cerami A, Brines M and Rosenbaum DM (2002) Erythropoietin administration protects retinal neurons from acute ischemia-reperfusion injury. Proc. Natl. Acad. Sci. USA 99: 10659-10664

90. Celik M, Gokmen N, Erbayraktar S, Akhisaroglu M, Konakc S, Ulukus C, Genc S, Genc K, Sagiroglu E, Cerami A and Brines M (2002) Erythropoietin prevents motor neuron apoptosis and neurologic disability in experimental spinal cord ischemic injury. Proc. Natl. Acad. Sci. USA 99: 2258-2263

91. Gorio A, Gokmen N, Erbayraktar S, Yilmaz O, Madaschi L, Cichetti C, Di Giulio AM, Vardar E, Cerami A and Brines M (2002) Recombinant human erythropoietin counteracts secondary injury and markedly enhances neurological recovery from experimental spinal cord trauma. Proc. Natl. Acad. Sci. USA 99: 9450-9455

92. Bianchi R, Buyukakilli B, Brines M, Savino C, Cavaletti G, Oggioni N, Lauria G, Borgna M, Lombardi R, Cimen B, Comelekoglu U, Kanik A, Tataroglu C, Cerami $A$ and hezzi $P$ (2004) Erythropoietin both protects from and reverses experimental diabetic neuropathy. Proc. Natl. Acad. Sci. USA 101: 823-828

93. Akisu M, Kullahcioglu Girgin F, Baka M, Husseyinov A and Kultursay N (2001) The role of recombinant human erythropoietin in lipid peroxidation and plateletactivating factor generation in a rat model of necrotizing enterocolitis. Eur. J. Pediatr. Surg. 11: 167-172

94. Akisu M, Tuzun S, Arslanoglu S and Yalaz M andKultursay N. (2001) Effect of recombinant human erythropoietin administration on lipid peroxidation and antioxidant enzyme(s) activities in preterm infants. Acta. Med. Okayama 55: $357-362$ 